Research Article

\title{
Research on Influence of Attribute Frame Effect on Loan Decision of Undergraduate and Risk Assessment Model of Undergraduate Loan Behavior
}

\author{
Jinsong Luan \\ Shenyang Sport University, Shenyang 110102, China \\ Correspondence should be addressed to Jinsong Luan; luanjs@syty.edu.cn
}

Received 24 March 2021; Revised 23 April 2021; Accepted 24 May 2021; Published 4 June 2021

Academic Editor: Jianhui Lv

Copyright (C) 2021 Jinsong Luan. This is an open access article distributed under the Creative Commons Attribution License, which permits unrestricted use, distribution, and reproduction in any medium, provided the original work is properly cited.

\begin{abstract}
The article uses virtual lending scenarios to study the influence of attribute frame effect on undergraduates' loan decisions. The results show that undergraduates have attribute frame effects in the three major areas of electronic products, life entertainment, and learning and training. There is a significant difference between the positive frame and the negative frame; that is, they are more inclined to make loan decisions under the positive frame. According to the research results, the article designs a loan risk assessment model based on Kohonen neural network and conducts simulation experiments. The experimental results show that the model' classification accuracy is $72.65 \%$.
\end{abstract}

\section{Introduction}

Nowadays, undergraduates' consumption concept such as comparison consumption and overspending has become prevalent. In 2009, the CBRC issued the Notice on Further Regulation of Credit Card Business, which demanded banks and financial institutions not to issue credit cards to students under 18-year-old. Besides, while issuing credit cards to students who have reached 18-year-old but do not have a stable income source, they need to achieve a second source of repayment with the ability to repay, after which major banks have tightened the credit card business to undergraduates. In contrast to the high threshold and severe audit of banks and financial institutions, peer-to-peer (P2P) lending platforms emerged in July 2013 and were favored by undergraduates for their convenience of application, simple procedures, rapid lending, and no mortgage. In order to improve the market share, the platforms have developed their business to universities and quickly developed P2P lending for undergraduates. Besides, to attract undergraduates to apply P2P lending, the platform usually attracts customers through inducing and opaque slogans. This makes it easy for uninitiated undergraduates to lose themselves in borrowing and consumption, making borrowing decisions that are not in line with their spending power. A range of negative events have occurred frequently since then, and even vicious events have happened. The chaos of campus P2P lending has alleviated since proposing the corresponding regulations and policies in 2016; thus, the use of campus P2P lending has been controlled. Simultaneously, the P2P lending platforms are not allowed to promote on campus, and universities have started to educate students to stay away from warning cases. By contrast, undergraduates who take P2P lending and installment consumption still occupy a particular proportion, and news of crisis made by the inability to repay the loan on time is common. Excessive repayment pressure can easily point to psychological crisis events. Additionally, regular overconsumption through $\mathrm{P} 2 \mathrm{P}$ lending will undoubtedly change students' consumption habits, affect credit, and carry a heavy burden to families, which is also a negative factor influencing social harmony and stability from the social prospect. Therefore, research on the psychology of undergraduates' $\mathrm{P} 2 \mathrm{P}$ lending consumption and introducing effective educational measures can overcome a range of negative effects of campus P2P lending. In the meantime, it can also lead undergraduates to construct 
rational consumption concepts and financial concepts and prevent crisis events.

The article uses virtual lending scenarios to study the influence of attribute frame effect on undergraduates' loan decisions and designs a loan risk assessment model to solve this situation.

\section{Related Work}

P2P (peer-to-peer) lending means the verification of relevant information, money issuance, contracts signing, and other related procedures and process, all realized through the Internet. P2P lending implies individual-to-individual lending, a financial model in which individuals present small loans to other individuals via a third party on the premise of charging interest. On the other hand, campus P2P lending determines the online financial service that integrates $\mathrm{P} 2 \mathrm{P}$ lending and network lending for college students.

Most borrowers of campus P2P lending platforms only require to implement a relevant proof of identity to apply for loans or installment consumption without collateral or guarantee. The platform does not rigidly examine the application information, and some platforms do not have the responsibility of due diligence; hence, undergraduates can use other students' identity information to reach loans quickly. The lax audit and inadequate supervision make it challenging for some students to get rid of it and make the platform full of risks.

In 2016, the Special Research Report on China's Campus Consumer Financial Market issued by Yiguan Think Tank surveyed 80 mainstream P2P lending platforms in the market [1]. The outcomes revealed that the average monthly interest rate was $0.92 \%$, which translated into monthly interest repayment and capital repayment, and the actual annualized interest rate was regularly over $20 \%$, some even up to $35 \%$. Once the repayment is overdue, $48 \%$ of the platforms have unknown overdue rates, and $58 \%$ of the platforms that clearly announce overdue rates have a daily rate of $1 \%$ after the overdue date. Subsequently, P2P lending platforms also have so-called service fees, default fees, and other charges, but they are never explicitly stated in the advertisements, attracting undergraduates to borrow with opaque and inducing advertising slogans.

The use of net loans for advanced consumption has become a common phenomenon among college students. In 2015, Tencent Technology published a survey entitled Report on the Real Demand for undergraduates' Installment of P2P Lending, which showed that approximately $60 \%$ of undergraduates used installment loans to buy electronic products and $39.8 \%$ of them were expected to borrow more than 2, 000 yuan, but $65.1 \%$ of them lived on only 500 yuan to 1,500 yuan per month at that time [2]. In 2016, in the Special Research Report on China's Campus Consumer Financial Market published by EnfoDesk, undergraduates utilized installment consumption relatively frequently, with $36 \%$ of active users and $66 \%$ stickiness to the installment platform, with $70 \%$ of males in installment consumption and $86 \%$ consumption took for purchasing electronic products [3]. In contrast to the extensive application of installment consumption for overspending, the 2017 Survey Report on the Credit Status of Chinese undergraduates released by CSCU revealed that only $65 \%$ of undergraduates who took campus loans would calculate the total cost of the loan [4]. However, 35\% of students did not even comprehend the actual cost of interest but only obey what the campus loan platform tells them. If they could not repay the loan on time, $42 \%$ of students did not ask their families for assistance, and $65 \%$ of them did not know their credit reports. Based on the Consumption Insight Report of College Students in 2018 released by iResearch, in 2017, the annual consumption scale of 30.18 million undergraduates was as high as 381.568 billion yuan [5]. The online e-commerce platform was the main channel for college students' consumption, and Ant Credit Pay and JD Baitiao were the preferred installment consumption techniques for undergraduates.

Jing surveyed 792 undergraduates in Yunnan, and the consequences explained that $33.2 \%$ of students had experienced P2P lending [6]. Fan managed a survey on students in six universities in Yunnan, and the outcomes revealed that $24.63 \%$ of students had adopted P2P lending, of which $55.71 \%$ were male students, $77.58 \%$ were senior students (juniors and seniors), and $85.39 \%$ of students had P2P lending of less than 5, 000 yuan [7]. Fu surveyed undergraduates, and the results explicated that $27 \%$ of students had applied P2P lending, 24.7\% of them regarded P2P lending to be safe, and $35.9 \%$ of them cited parents and online reviews as the main influencing factors for P2P lending determination [8]. Cong et al. surveyed 672 students in one of the universities in Shanghai, and the outcomes proved that $56.1 \%$ of students had taken P2P lending online loan platforms, with a higher proportion of male students utilizing P2P lending, accounting for $61.02 \%$, and $53.44 \%$ of female students [9].

In 2015, CMRC and Beijing Yixin Zhicheng Credit Management Co., Ltd. jointly published the Kindling Project-National Research Report on undergraduates' Credit Awareness-which revealed that most undergraduates who lacked a reasonable budget for money have a weak awareness of P2P lending and were significantly lacking in credit knowledge. Meanwhile, more than $80 \%$ of undergraduates did not comprehend personal credit reports, and $30 \%$ did not understand that overdue records would be recorded in personal credit reports and influenced their future financial lives [3]. Furthermore, only $12 \%$ of them knew that the overdue records in credit reports were kept for several years, and $40 \%$ of them were late in repayment, and $10 \%$ of them repaid through borrowing.

The trend of consumerism has enhanced society's mainstream and has exceedingly affected contemporary undergraduates' consumption concept. Contemporaneously, the spurt development of major e-commerce platforms and the overwhelming advertisements of large and small consumer festivals continually influence undergraduates' rational nerves. Consumerism is constantly alienating people's economic behavior, and bad trends simply affect undergraduates whose world and life perspective values are 
not yet completely built up to make irrational behavioral decisions.

According to Erikson's theory of psychological development step, undergraduates are in self-identity integration. At this step, the group of undergraduates has the compelling requirement for identity, and the internal standards will turn into the guidelines that undergraduates have to obey; otherwise, they will feel tremendous internal and external pressure. The same is true for the consumption process. In consumption, undergraduates will consume and pick goods through imitation, conformity, and assimilation to obtain their peers' praise or envy. This variety of consumer behavior is also one of the triggers for blind, irrational consumption.

Currently, the laws, regulations, and industry self-regulation norms for $\mathrm{P} 2 \mathrm{P}$ lending are not yet perfect. In order to reach the enormous profit of undergraduates, primary campus P2P lending platforms utilize advertising, QQ groups, WeChat official accounts, Weibo, and other communication media to incite the excessive consumption of undergraduates to expand market share. They induce undergraduates to take out P2P lending with advertisements such as "without a down payment, zero interest rate, no collateral, receive the payment in ten minutes" and deliberately evade the description of borrowing risks. If undergraduates are late in repaying the loan, the P2P lending platform employs malicious disclosure, harassment, threats to violently drew the loan, or illegally applies the student's personal information for personal gain.

\section{Research on the Influence of Attribute Frame Effect on the Loan Decision of Undergraduate}

3.1. Attribute Framing Effects. In 1981, Kahneman and Tversky discovered a framing effect in the decision-making process, i.e., changing the expression form of essentially the same decision plan could inspire people to make diverse decisions [10]. Levin et al. defined the framing effect into risky choice framing effect, attribute framing effect, and goal framing effect based on three dimensions: the object being framed, the object influenced by the framing, and the standard measurement of the effect, and argued that the three types of framing effects were independent of each other and symbolized separate processing processes [11].

The attribute framing effect refers to the fact that a consequence or event can be rated separately in attractiveness based on some of its attributes $d_{1}, d_{2}, d_{3} \ldots, d_{n}$, with positive framing showing the attribute as $\mathrm{A}+$ (e.g., success, getting slender) and negative framing revealing it as A- (e.g., failure, getting fatter). The attribute framing effect indicates that subjects are more inclined to make higher attractiveness ratings for consequences or events in the $\mathrm{A}+$ context relative to consequences or events in the A- context.

The attribute framing effect has two characteristics as follows. (1) The risk-free attribute framing effect involved only the rating of things and did not include the choice of risky conditions, whereas the choice of risky conditions was present in the risk framing effect and the goal framing effect (see Levin et al. [11]). (2) The specificity attribute framing effect only impacted the rating process of commodity rating, performance appraisal, and gambling (see Wen et al. [12]), whereas the risk and goal framing were pervasive (see Levin et al. [11]). For example, if a student requires to borrow 6, 000 yuan to get a cell phone, one lending platform defines "borrowing for 12 months with a monthly repayment of 580 yuan." Another platform describes "borrowing for 12 months interest-free, but you have to pay a monthly fee of $\$ 80$." In the same repayment amount, only the variation in the described approach can surely influence the undergraduates' P2P lending decision. Various P2P lending platforms utilize this kind of inducement or ambiguous slogan to attract undergraduates to choose them.

3.2. Research Subjects and Research Methods. The research subjects were students from the first to the fourth year in one of the universities in Shenyang, 600 questionnaires were distributed according to random sampling, and 581 valid questionnaires were obtained. Among them, 342 (58.9\%) were male students, 239 (41.1\%) were female students, 198 (34.1\%) were first-year students, 166 (28.6\%) were secondyear students, $123(21.2 \%)$ were third-year students, and 94 (16.2\%) were fourth-year students. The questionnaire was self-administered, and the questions were designed to know undergraduates' P2P lending consumption and the impact of the attribute framing effect on $\mathrm{P} 2 \mathrm{P}$ lending decisions.

3.3. Undergraduates' Consumption of $P 2 P$ Lending. This paper intuitively knew the usage and distribution features of undergraduates' monthly living expenses through the questionnaire survey. The total monthly living expenses of RMB 1000 and below valued for 9.1\%, RMB 1000 to 1500 occupied for $34.9 \%$, RMB 1500 to 2000 accounted for $32.5 \%$, RMB 2000 to 2500 valued for $16.5 \%$, and RMB 2500 and above occupied for $6.9 \%$, with average monthly living expenses of RMB 1656.9. In general, there was a certain gap in the level of expenses among individual undergraduates.

The distribution of living expenses was principally focused on six areas: food and drink, clothing, shoes, and hats, make-up and daily necessities, electronic products (including game equipment), living and entertainment, and learning and training. The proportion of food and drink valued for the most significant proportion of monthly expenses accounted for $35 \%$ to $55 \%$ of monthly expenses, with only $6.8 \%$ of students accounted for less than 35\% (Table 1). It was noteworthy that gatherings, a common form of daily interaction among undergraduates, also occupied a specific proportion of monthly expenses. There was a meaningful variation between male and female students in three categories of living expenses: clothing, shoes, and hats, cosmetics, and electronic products (including gaming devices). Among the females, $60.1 \%$ spent more than $20 \%$ on clothing and shoes and $51.2 \%$ spent more than $20 \%$ on daily necessities. The proportion of males who spent more than $20 \%$ in these two categories was lower, $41.2 \%$ and $19.7 \%$, individually. In electronics (including gaming devices), 32\% of the males spent more than $15 \%$ of their monthly electronic products expenses. In terms of living and entertainment expenses, $64 \%$ of females spent more than $20 \%$ of their monthly expenses 
TABLE 1: Undergraduates' perception of P2P lending consumption.

\begin{tabular}{|c|c|c|c|c|c|}
\hline \multirow{2}{*}{$\begin{array}{l}\begin{array}{l}\text { Serial } \\
\text { no. }\end{array} \\
1\end{array}$} & Issue & \multicolumn{4}{|c|}{ Option percentage } \\
\hline & Knowledge of $\mathrm{P} 2 \mathrm{P}$ lending process and business & $\begin{array}{l}\text { Do not understand } \\
9.0 \%\end{array}$ & $\begin{array}{l}\text { Do not know } \\
\text { much } 60.1 \%\end{array}$ & $\begin{array}{l}\text { Better understand } \\
25.5 \%\end{array}$ & $\begin{array}{c}\text { Know well } \\
5.5 \%\end{array}$ \\
\hline 2 & Understand the channels of P2P lending & $\begin{array}{l}\text { Network platform } \\
35.9 \%\end{array}$ & $\begin{array}{l}\text { Media advertising } \\
28.2 \%\end{array}$ & $\begin{array}{l}\text { Classmates and } \\
\text { friends } 31.2 \%\end{array}$ & $\begin{array}{c}\text { Relatives } \\
4.8 \%\end{array}$ \\
\hline 3 & $\begin{array}{l}\text { Will the comprehensive cost of interest be } \\
\text { measured before applying the P2P lending? }\end{array}$ & \multicolumn{2}{|c|}{ Yes $53 \%$} & \multicolumn{2}{|c|}{ No $47 \%$} \\
\hline 3 & Whether P2P lending is safe or not & \multicolumn{2}{|c|}{ Yes $35.5 \%$} & \multicolumn{2}{|c|}{ No $64.5 \%$} \\
\hline 4 & Attitude towards P2P lending & Convenient $47.8 \%$ & $\begin{array}{c}\text { Low threshold } \\
54 \%\end{array}$ & High interest $72.1 \%$ & $\begin{array}{l}\text { High risk } \\
67.1 \%\end{array}$ \\
\hline 5 & $\begin{array}{l}\text { Will you ask your family for help when you } \\
\text { cannot make repayments on time? }\end{array}$ & \multicolumn{2}{|c|}{ Yes $21.9 \%$} & \multicolumn{2}{|c|}{ No $78.1 \%$} \\
\hline 6 & $\begin{array}{c}\text { How much do you know about personal credit } \\
\text { reports? }\end{array}$ & $\begin{array}{l}\text { Do not understand } \\
\quad 32.5 \%\end{array}$ & $\begin{array}{l}\text { Do not know } \\
\text { much } 42.2 \%\end{array}$ & $\begin{array}{l}\text { Better understand } \\
17.6 \%\end{array}$ & $\begin{array}{l}\text { Know well } \\
7.7 \%\end{array}$ \\
\hline
\end{tabular}

and $61 \%$ of males spent more than $20 \%$ of their monthly expenses, so it could be observed that living and entertainment expenses were more extensive in the undergraduates. The proportion of learning and training consumption was low, with $89 \%$ of them spent less than $10 \%$ of their monthly expenses on learning and training, and the difference between male and female students was not noticeable.

The survey revealed that undergraduates' awareness of online loans was inadequate, and the phenomenon of insufficient financial knowledge was still common. The outcomes showed that $70 \%$ of undergraduates did not know much or even comprehend the process of P2P lending, and only half of them would determine the comprehensive cost of interest before applying P2P lending. Approximately 80\% of them would not ask for help from their families if they could not repay the loan on time, and less than $30 \%$ of them knew about their credit reports (Table 2). Online platforms and friends were the main channels for them to learn about P2P lending.

The investigation revealed that only $30 \%$ of undergraduates would decide to give up consumption if their living expenses cannot satisfy their expenses, and the awareness of rational consumption was inadequate. Among them, females were comparatively more rational, and $68 \%$ of the people who gave up consumption were females. $12.2 \%$ of undergraduates have utilized $\mathrm{P} 2 \mathrm{P}$ lending, and the main reasons for taking $\mathrm{P} 2 \mathrm{P}$ lending were low threshold and fast lending. Classmates and friends and interest rates were the main reasons for taking $\mathrm{P} 2 \mathrm{P}$ lending; $70 \%$ of them took $\mathrm{P} 2 \mathrm{P}$ lending with RMB 2,000 to 4,000 yuan for consumption and shopping (Table 2).

\subsection{The Influence of Attribute Framing Effect on the Loan} Decision of Undergraduate. The attribute framing effect only influences the evaluation process of commodity evaluation, performance assessment, and gambling. As a result, relying on the attribute framing effect, this article also composed a virtual borrowing scenario to analyze further the effect on undergraduates' lending decisions.

The virtual P2P lending scenario materials are extracted from a specific characteristic of the commodity, and the positive frame designates this characteristic positively
(Table 3). In contrast, the negative frame describes it negatively to investigate whether the lending description affects the reception decision. According to undergraduates' life scenarios, this research picked electronic products, living and entertainment, and learning and training among the six major life expenses for the material design. The three scenarios of purchasing cell phones, travel expenses, and insufficient training expenses were adopted to represent positively and negatively, and the responses were scored on a five-point Likert scale.

Undergraduates had attribute framing effects in the three major areas of electronic products, living and entertainment, and learning and training, and the distinction between positive and negative frames was meaningful (Table 4 ). That is, they were more inclined to make borrowing decisions under the positive frame. Accordingly, the description of borrowing matters by lending platforms could widely impact undergraduates' borrowing behavior. The demographic variable analysis also revealed no critical difference in undergraduates' borrowing decisions with various living expenses and diverse genders in the three major domains under the attribute framework (Tables 5 and 6).

3.5. Discussion. The survey explained that subsistence consumption and enjoyment consumption were the principal consumption patterns of undergraduates, particularly enjoyment consumption accounts for a higher proportion. On the other hand, the proportion of developmental consumption was comparatively low, the proportion of overconsumption was high, and the phenomenon of inadequate knowledge of P2P lending and insufficient financial knowledge was also widespread. Meanwhile, the attribute framing effect also had an essential influence on the borrowing decision process, and the induced slogan of P2P lending platforms might influence undergraduates to determine to borrow blindly. Therefore, it was crucial to promoting financial literacy and mastered financial knowledge for undergraduates. University should develop education channels, supervise undergraduates to launch rational consumption concepts, master financial credit knowledge, and enhance financial management ability and 
TABLE 2: The consumption status of undergraduates' P2P lending.

\begin{tabular}{|c|c|c|c|c|c|}
\hline $\begin{array}{l}\text { Serial } \\
\text { no. }\end{array}$ & Issue & \multicolumn{4}{|c|}{ Option percentage } \\
\hline 1 & $\begin{array}{l}\text { While living expenses } \\
\text { cannot satisfy expenses }\end{array}$ & $\begin{array}{c}\text { Give up spending } \\
34 \%\end{array}$ & $\begin{array}{c}\text { Borrow from friends and } \\
\text { relatives } 10.1 \%\end{array}$ & $\begin{array}{l}\text { Use consumption } \\
\text { installment } 41.5 \%\end{array}$ & $\begin{array}{c}\text { Use P2P lending } \\
14.3 \%\end{array}$ \\
\hline 2 & $\begin{array}{c}\text { Have you used P2P } \\
\text { lending? }\end{array}$ & \multicolumn{2}{|c|}{ Yes $12.2 \%$} & \multicolumn{2}{|c|}{ No $87.8 \%$} \\
\hline 3 & $\begin{array}{l}\text { Reasons for selecting P2P } \\
\text { lending }\end{array}$ & $\begin{array}{c}\text { Convenient audit } \\
17.6 \%\end{array}$ & Low threshold $35.5 \%$ & $\begin{array}{c}\text { Quick release of funds } \\
38.9 \%\end{array}$ & $\begin{array}{c}\text { Flexible repayment } \\
8 \%\end{array}$ \\
\hline 4 & $\begin{array}{c}\text { Reasons that affect the } \\
\text { choice }\end{array}$ & $\begin{array}{c}\text { Online review } \\
16.9 \%\end{array}$ & \multicolumn{2}{|c|}{ Classmates and friends 53\% } & Interest $30.1 \%$ \\
\hline 5 & $\begin{array}{c}\text { Choose the amount of P2P } \\
\text { lending }\end{array}$ & $\begin{array}{c}\text { Less than } 2000 \\
18.2 \%\end{array}$ & 2000 to $300039.4 \%$ & 3000 to $400032 \%$ & $\begin{array}{c}\text { More than } 4000 \\
10.3 \%\end{array}$ \\
\hline 6 & Use of $\mathrm{P} 2 \mathrm{P}$ lending funds & $\begin{array}{c}\text { Temporary } \\
\text { emergency } 17 \%\end{array}$ & $\begin{array}{l}\text { Consumption and } \\
\text { shopping } 70.2 \%\end{array}$ & $\begin{array}{l}\text { Learning and training } \\
5.2 \%\end{array}$ & $\begin{array}{c}\text { Entrepreneurship } \\
7.6 \%\end{array}$ \\
\hline
\end{tabular}

TABLE 3: Materials for virtual scenarios.

\begin{tabular}{|c|c|c|}
\hline Living expenses & $\begin{array}{l}\text { Description } \\
\text { frame }\end{array}$ & Scenario material \\
\hline Electronic product & Negative frame & $\begin{array}{l}\text { Suppose you intend to buy a new mobile phone, but the price of } 6000 \text { yuan is beyond your } \\
\text { budget, and now a P2P lending platform proposes installment purchase business with fees. If you } \\
\text { choose } 12 \text { installments, you need to repay } 500 \text { yuan per month. How much are you willing to } \\
\text { pick the P2P lending at this time? } \\
\text { Suppose you intend to buy a new mobile phone, but the price of } 6000 \text { yuan is beyond your } \\
\text { budget, and now a P2P lending platform proposes installment purchase business with fees. If you } \\
\text { choose } 12 \text { installments, you need to pay an extra fee of } 80 \text { yuan per month. How much are you } \\
\text { willing to pick the P2P lending at this time? }\end{array}$ \\
\hline \multirow{2}{*}{$\begin{array}{l}\text { Living and } \\
\text { entertainment }\end{array}$} & Positive frame & $\begin{array}{l}\text { Suppose you plan to travel with your classmates during the short holiday, but the cost of } 3,000 \\
\text { yuan surpasses your living budget. Currently, a P2P lending platform drives a one-month } \\
\text { interest-free loan service. If the lending is fast within one month, no interest is required. To } \\
\text { repay, you demand to repay } 0.2 \% \text { of the loan amount every day, that is, to repay an extra } 6 \text { yuan } \\
\text { in interest every day. How much are you willing to pick the P2P lending at this time? }\end{array}$ \\
\hline & Negative frame & $\begin{array}{l}\text { Suppose you plan to travel with your classmates during the short holiday, but the cost of } 3,000 \\
\text { yuan surpasses your living budget. Currently, a P2P lending platform drives a one-month } \\
\text { interest-free loan service. If the lending is fast within one month, no interest is required. To } \\
\text { repay, you need to repay } 6 \% \text { of the loan amount every month, that is, to repay an additional } 180 \\
\text { yuan in interest per month. How much are you willing to pick the P2P lending at this time? }\end{array}$ \\
\hline \multirow{2}{*}{ Learning and training } & Positive frame & $\begin{array}{l}\text { Suppose you plan to engage in an overseas study tour during the holiday, but the cost of } 6000 \\
\text { yuan surpasses your living budget. Currently, a P2P lending platform establishes a six-month } \\
\text { low-interest loan business, charging a service fee of } 1.7 \% \text { of the loan amount per month, which is } \\
100 \text { yuan per month, if you pay back on time for the month. How much are you willing to pick } \\
\text { the P2P lending at this time? }\end{array}$ \\
\hline & Negative frame & $\begin{array}{l}\text { Suppose you plan to engage in an overseas study tour during the holiday, but the cost of } 6000 \\
\text { yuan surpasses your living budget. Currently, a P2P lending platform establishes a six-month } \\
\text { low-interest loan business, charging a service fee of } 10 \% \text { of the loan amount, which is } 600 \text { yuan } \\
\text { per month, if you pay back on time for the month. How much are you willing to pick the P2P } \\
\text { lending at this time? }\end{array}$ \\
\hline
\end{tabular}

TABLE 4: Under the attribute framework, the differences in the loan decisions of undergraduates in the three scenarios.

\begin{tabular}{lcc}
\hline Living expenses & Description frame & $t$ \\
\hline Electronic product & Positive frame & $1.874^{* *}$ \\
Living and entertainment & Negative & frame \\
& Positive frame & $3.016^{* *}$ \\
Nearning and training & frame & \\
& Positive frame & $4.285^{*}$ \\
& Negative frame & \\
\hline Note. $^{*}: p<0.05 ;{ }^{* *}: p<0.01 ;{ }^{* * *}: p<0.001$.
\end{tabular}

TABle 5: Comparison of decision-making differences between various levels of living expenses under the attribute framework.

\begin{tabular}{lcc}
\hline Serial no. & Areas of living expenses & $F$ \\
\hline 1 & Electronic product & 0.26 \\
2 & Living and entertainment & 0.315 \\
3 & Learning and training & 0.248 \\
\hline Note. ${ }^{*}: p<0.05 ;{ }^{* *}: p<0.01 ;{ }^{* * *}: p<0.001$. &
\end{tabular}


TABle 6: Comparison of decision-making differences between different genders under the attribute framework.

\begin{tabular}{llc}
\hline Serial no. & Areas of living expenses & $T$ \\
\hline 1 & Areas of living expenses & 1.7 \\
2 & Electronic product & 0.98 \\
3 & Living and entertainment & 1.45 \\
\hline
\end{tabular}

Note. ${ }^{*}: p<0.05 ;{ }^{* *}: p<0.01 ;{ }^{* * *}: p<0.001$.

self-planning. Moreover, to advance financial management ability and self-planning level, undergraduates were assisted to keep rational consumption in the contemporary society where consumerism was prevalent, the spirit of struggle was stimulated, and self-development was made the main theme of university life.

\section{The Risk Assessment Model of Undergraduate Loan Behavior}

4.1. Kohonen Neural Network-Based Risk Assessment Model. Artificial neural network (ANN) is based on the basic principles of neural networks in biology. After comprehending and abstracting the structure of the human brain and the response mechanism of external stimuli, it is a mathematical model that affects the processing mechanism of the human brain's nervous system for complex information under the theoretical knowledge of network topology. This model is characterized by parallel distributed processing capability, high fault tolerance, intelligence, and self study, and this model combines information processing and storage. Meantime, its unique knowledge representation and intelligent adaptive learning capability have attracted attention in multiple disciplines [13].

Kohonen network is a self-organizing feature mapping network introduced by Professor Kohonen in Finland. In the biological nervous system, there is a phenomenon of lateral inhibition; that is, after a nerve cell is stimulated, it will have an inhibitory impact on the surrounding cells. This inhibition will provoke competition between nerve cells. The competition's outcome is that the winner is excited, and the loser is inhibited, and the Kohonen network copies this biological phenomenon. If a neural network accepts external input patterns, it will be split into numerous corresponding areas. Every area has diverse response features to the input mode, and this process is done automatically. The self-organizing feature map is based on this prospect, and its features are similar to the self-organizing feature of the human brain. Kohonen neural network is an unsupervised learning neural network with self-organization function. Through its own training, the network can automatically classify the input mode.

In terms of network structure, it is regularly a two-layer network consisting of an input layer and a competing layer. The neurons between the two layers fulfill bidirectional connections, and the network has no hidden layer. Sometimes there are also lateral connections between the neurons in the competitive layer. In the learning algorithm, it mimics the kinetic principles of excitation, coordination, and inhibition, and competitive action of information processing between biological neurons to manage the learning and working of the network, unlike most neural networks that utilize the mistake or energy function of the network as the criterion of the algorithm.

The basic idea of the competitive neural network is that each neuron in the network competes to reply to the input pattern. Eventually, only one neuron converts the winner of the competition. This winning neuron designates the classification of the input pattern. In the competition layer, only one winning neuron will be generated for each sample input [14]. Considering that the input layer has $m$ neurons and the core layer has $n$ neurons, the weight should be an $\mathrm{m} * \mathrm{n}$ matrix. If the input vector is $p=\left[p_{1}, p_{2}, \ldots, p_{n}\right]$, the output of the network is $Y=P_{\omega}$. In reply to the $n$ neurons in the competition layer, one neuron must become the winning neuron $Y_{k}$. The weight correction method of the winning neuron is $\Delta \omega_{i k},=\eta\left(\mathrm{P}_{i}-\omega_{i k}\right) Y_{k}$. It can be observed that the weight is close to the sample $P i$ at a rate of $\eta$ because the weight of the winning neuron $Y_{k}$ is near to the input sample $P_{i}$. Consequently, $Y_{k}$ has a more prominent probability of winning in the next iteration. If the step size of the rate $\eta$ is suitable, the input sample's network weight corresponding to the winning neuron will approach the input sample, and the gap will become smaller and tinier [15].

In order to accommodate the characteristics of online lending and borrowing decisions, the Kohonen network is enhanced to make it clustered. An additional output layer is added after the competitive layer to turn it into a supervised learning network [16]. The number of neurons in the added output layer is identical to the number of suitable categories in the database. The neurons' connection weights in the output layer and the neurons in the competitive layer are $\omega_{j k}$. If the weights are modified, the weights of the input layer and those of the competing layer and the output layer are adjusted concurrently in two categories, and the weights are adjusted as $\omega_{j k}(n+1)=\omega_{j k}(n)+\eta_{2}\left(Y_{k}-\omega_{j k}(n)\right)$. Among them, $\omega_{j k}$ is the weight between the core and output layers, $\eta_{2}$ is the learning rate, and $Y_{k}$ is the actual class to which the sample belongs.

The borrowing risk of undergraduates principally includes both personal factors and platform factors. In accordance with this study's outcomes, age and gender influence borrowing decision, and consumption and personal credit status can also effectively evaluate undergraduates' daily consumption level and credit history. The platform factors comprise the information attribute framework of $\mathrm{P} 2 \mathrm{P}$ lending in this research and the interest rate, late interest rate, and default loss of lending. If the P2P platform presents information through an active framework, the borrowing interest rate and overdue interest rate are not high, and the default loss is small, and undergraduates will make borrowing decisions. Hence, undergraduates' borrowing risk model indicators involve age, gender, consumption, personal credit status, attribute framework of $\mathrm{P} 2 \mathrm{P}$ lending information, interest rate, overdue interest rate, and default loss. Since the neural network cannot identify the textual content, the chosen model indicators are numerically transformed before simulation training. Every indicator's textual information 
is quantified into a distinct value between $[0,1]$ according to the probability size of default risk.

The simulation experiment of the model selects the data set of the number of loan borrowers as the analysis sample, of which 34 are nondefaulting borrowers, 16 are default borrowers, and the credit rating is $\mathrm{A}$ (the highest grade), $\mathrm{B}$, C, D, E, and HR (the lowest grade). With the chosen 8 indicators as input, the number of neurons in the input layer is set to 8 , the distance function is set to the dist function, the network topology is $8 * 8$, that is, the competition layer has 64 neurons, and the number of network learning is 10000 times. The data set comprises 6 varieties of credit ratings, so there are 6 varieties of the data set, and hence 6 extra input layer neurons are added.

4.2. Simulation Results. Simulation experiments are managed based on the MATLABR2014b platform, and the results are revealed in Table 7. The overall accuracy of the model is $72.65 \%$, the data volume of defaulted borrowers with $\mathrm{E}$ credit rating is small, and the sample learning is not adequate (Table 7). As a result, the accuracy rate is lower, and each credit rating model's prediction ability is more vital for the other two kinds of borrowers.

\section{Recommendations}

5.1. Improve Laws and Regulations and Complete Regulatory Mechanism. As a new variety of lending, P2P lending has implemented numerous impetus to developing the financial industry. However, a thorough regulatory mechanism has not been built in time with the industry's successful development, making a range of social problems in the early stage of development. Some of the regulations in the Contract Law of the People's Republic of China and the Opinions of the Supreme People's Court on the Trial of Lending Cases by the People's Courts are currently the relevant legal basis for P2P lending. With the spurt of developing $\mathrm{P} 2 \mathrm{P}$ lending, related departments have published management measures to manage it one after another. In 2015, the Central Bank led the formulation of the Guiding Opinions on Promoting the Healthy Development of Internet Finance, which supervised network lending, a component of the seven major Internet finance industries. In 2016, the China Banking Regulatory Commission took the lead in composing the Interim Measures for the Management of the Business Activities of Online Lending Information Intermediaries to strengthen the supervision and management of the P2P lending information intermediaries' business activities. In 2019, the leading group for the special rectification of Internet financial risks and the leading group for the special rectification of online lending risks jointly issued the Notice on Strengthening the Construction of the Credit Investigation System in the P2P Lending Field to assist the access of $\mathrm{P} 2 \mathrm{P}$ lending institutions in operating credit investigation system. Although relevant management measures have been introduced for regulation, the network platform carries significant regulation challenges while being convenient and productive. Clear regulatory responsibilities, increasing supervision, establishing early warning mechanisms, reducing nonperforming loans, and improving the credit system have become essential safeguards to guarantee the healthy development of the P2P lending industry. Consequently, the relevant departments should continue to advance laws and regulations and enhance the regulatory mechanism to escort Internet finance development.

\subsection{Rectify the Chaos of the Industry and Manage Healthy} Development. In accordance with the monitor from $\mathrm{Na}$ tional Internet Financial Security Technical Expert Committee, as of the end of July 2017, only 153 of the more than 2, 000 platforms involved in cash loans and other small P2P lending businesses in the market had reached small P2P lending licenses. In 2017, the Office of the Leading Group for Special Work on Internet Financial Risks issued a Notice on the Immediate Suspension of the Establishment of Small P2P Lending Companies. It determined that the regulatory authorities of small P2P lending companies at each level shall not allow new small P2P lending companies and forbid new batches of microfinance companies to achieve small P2P lending companies across provinces (districts and cities). Apart from the shortage of qualifications, numerous online lending platforms do not have professional financial services and cannot present specialized services. Under the premise that China has increased the industry threshold and suspended approval, the industry should strengthen self-discipline within the industry, define industry self-regulation norms immediately, and reduce induced advertising. Consistently, interest rate repayment transparency advances practitioners' professional level and supervises the industry's healthy and orderly development.

\subsection{Advance Financial Education and Supervise Rational} Consumption. Since P2P lending has turned into a social issue, universities attach prominent importance to educational warnings and operational supervision. Nevertheless, most of the education process is based on case warning education and consumption concept guidance, and there is less education on financial literacy and financial planning. Accordingly, university students usually lack financial knowledge, credit knowledge, and inadequate financial management ability and are simply influenced by induced consumption. As a result, universities should encourage financial education, concentrating on improving financial literacy, financial knowledge, personal credit investigation, and other financial literacy. Conformably, relying on innovation and entrepreneurship education, schools should lead university students to build up a rational consumption concept, enhance the spirit of struggle, and transition to the university campus with higher personal qualities and a positive condition of hard work.

\subsection{Strengthen One's Literacy and Rational Career Planning.} University students themselves should launch a rational consumption outlook and a developmental consumption outlook, take the initiative to master the knowledge of 
TABLE 7: Simulation outcomes.

\begin{tabular}{lcccccc}
\hline & Credit rating & Quantity & Number of correct classifications & - & Accuracy (\%) & - \\
\hline Nondefault borrowers & A & 12 & 10 & $83.3 \%$ & 76.5 & $72.65 \%$ \\
- & B & 8 & 6 & 6 & $75 \%$ & - \\
- & C & 8 & 4 & $75 \%$ & - & - \\
- & D & 6 & 3 & $66.7 \%$ & - & - \\
\hline Default borrower & C & 5 & 3 & $60 \%$ & 68.8 & - \\
- & D & 4 & 1 & $75 \%$ & - \\
- & E & 2 & 4 & $80 \%$ & - \\
- & HR & 5 & - & - \\
\hline
\end{tabular}

financial credit investigation, and improve their financial management ability. Under the premise of guaranteeing survival consumption, more expenditures will be utilized for developmental consumption to lay a stable foundation for further career development. At the moment, it will strengthen its innovation and entrepreneurship capabilities, making full use of professional advantages and personal expertise to accomplish part-time and entrepreneurial activities actively. Besides, a spirit of hard work and enterprising is organized, and financial independence is carried out while transitioning to society.

\section{Conclusion}

The attribute framework effect has an important influence in the lending decision-making process. The inductive slogans of online lending platforms can easily lead college students to blindly choose loans. Therefore, improving financial literacy and mastering financial knowledge are very important for college students. The loan risk assessment model based on Kohonen neural network has strong predictive ability. When the amount of data is sufficient, it shows better risk assessment ability. The application of this model to guide individuals with larger loan risk predictions can effectively avoid the behavior of borrowing and lending in breach of contract protects individual interests and forms a rational consumption concept.

The limitation of this study is that the influence of other frame effects on lending behavior is not discussed, and a comprehensive model is not established. Future research can carry out in-depth research on this content.

\section{Data Availability}

The data used to support the findings of the study are included within the article.

\section{Conflicts of Interest}

The author declares that there are no conflicts of interest.

\section{References}

[1] Yiguan Think Tank, The Special Research Report on China's Campus Consumer Financial Market [EB/OL], 2016, https:// www.sohu.com/a/63680354_334205.

[2] Tencent, . Report on the Real Demand for Undergraduates' Installments of $P 2 P$ Lending [EB/OL], Tencent, Shenzhen, China, 2015, https://tech.qq.com/a/20150121/011525.htm.
[3] Beijing Yixin Zhicheng Credit Management Co., Ltd. and CMRC, Kindling Project: National Research Report on undergraduates' Credit Awareness [EB/OL], 2015, http://sf.ruc. edu.cn $/$ ? $\mathrm{p}=388$.

[4] Research Consumption Insight Report of College Students in 2018 [EB/OL], 2018, http://report.iresearch.cn/report/201808/ 3262.shtml.

[5] CSCU, 2017 Survey Report on the Credit Status of Chinese Undergraduates [EB/OL], 2017, https://www.iyiou.com/p/52180. html.

[6] Y. Jing, Research on the Consumption Behavior and Psychology of Undergraduates' Campus P2P Lending, Yunnan University, Kunming, China, 2017.

[7] L. Fan, R. Gan, X. Fan, S. Xu, Yu Gao, and M. Li, “Analysis of undergraduates' problems and countermeasures of P2P lending-taking the universities in chenggong city as an example," Times Finance, vol. 11, pp. 106-107, 2017.

[8] X. Fu, "Research on the deconstruction and inhibition of undergraduates' P2P lending consumption behavior," Journal of Southwest Normal University (Natural Science Edition), vol. 8, pp. 128-133, 2017.

[9] L. Cong, Y. Yuan, and X. Yan, "A study on the correlation between undergraduates' consumption and P2P lending behavior based on questionnaire survey-taking one of the universities in Shanghai as an example," Consumer Economics, vol. 94, no. 1, pp. 94-96, 2019.

[10] D. Kahneman and A. Tversky, "The framing of decisions and the psychology of choice," American Association for the Advancement of Science, vol. 211, no. 4481, pp. 453-458, 1981.

[11] I. P. Levin, S. L. Schneider, and G. J. Gaeth, "All frames are not created equal: a typology and critical analysis of framing effects," Organizational Behavior and Human Decision Processes, vol. 76, no. 2, pp. 149-188, 1998.

[12] G. Wen, F. Xu, H. Yu, B. Huang, and L. Wang, "The psychological mechanism and influencing factors of the characteristic frame effect," Advances in Psychological Science, vol. 19, no. 12, pp. 1822-1833, 2011.

[13] T. Kohonen, Self-Organization and Associative Memory, Springer, vol. 8pp. 3406-3409, Berlin, Germany, 3rd edition, 2006.

[14] L. Ma, S. Cheng, and Y. Shi, "Enhancing learning efficiency of brain storm optimization via orthogonal learning design," IEEE Transactions on Systems, Man, and Cybernetics: Systems, vol. 1109, no. 10, pp. 1-20, 2020.

[15] C. Sun, Y. Sun, and K. Xie, "Mind-evolution-based machine learning:an efficient approach of evolution computation," in Proceedings of the 3rd World Congress on Intelligent Control and Automation (Cat. No.00EX393), Hefei, China, June 2000.

[16] Z. Zhang, N. Zhou, and J. Fan, "P2P online loan borrower credit risk assessment model-optimize SKohonen neural network based on thought evolution algorithm," Taxation and Finance, vol. 20, no. 10, pp. 84-85, 2020. 